\title{
Yachting and coastal marine transport devel- opment in Black Sea coast of Russia
}

\author{
Yuriy Dreizis ${ }^{1}$ and Irina Potashova ${ }^{1}$ \\ ${ }^{1}$ Sochi State University, 26-A Sovietskaya str., Sochi, 354000, Russia
}

\begin{abstract}
Creation of infrastructure for coastal sea passenger transport and yachting along the Black Sea coast of Russia is one of the important directions of development potential of coastal cities. This infrastructure will allow increasing significantly quality of the recreation, to diversify tourist activity (tourism, hotel business, etc.). Creation of modern yacht-harbors, reconstruction and development of port piers for coastal passenger transport will allow increasing in essence quality of tourism and developing touristic activity in the region. The basic principles are defined for the analysis of requirements and existing conditions of the territory and the prospects of development of the Russian coast. They take into account all aspects of functioning of yacht-harbors and port piers as one of the most important elements of development of seaside city.
\end{abstract}

\section{Introduction}

Russia has the site of the Black Sea coast including the coast of the Crimea and the coast of Krasnodar region. The Black Sea coast of Russia is the only region in the country where there is an opportunity for year-round functioning of objects of the sea resort. However, development of the coast goes without system approach to optimum development of his sea potential. The result of this is fragmentary unbalanced development of the coastal territory and as consequence - violation of the natural mode of the coast development, loss of valuable coastal territories; expenses unjustified economical and need of performance of protection actions of coast [1-5].

The developed infrastructure of coastal cities, tendencies of dynamics of their development is an important condition of development of the coast. [1-5].

The available experience of development and use of coastal territories of recreational orientation is one more defining condition. It is based on achievements in construction and operation of objects of resort infrastructure and yachting.

Beaches complexes and infrastructure facilities of yachting are basic elements on which the industry of service of tourists on the seacoast leans. Modern practice of functioning of sea resorts confirms the prevailing influence of beaches complexes and objects of yachting in coastal region. The coastal region will be able to become the full-fledged sea resort only if he is able to use as much as possible all natural resources of the seacoast. The optimum combination of natural factors of the coast and engineering and technological methods of

\footnotetext{
${ }^{1}$ Corresponding author: Yurid2006@yandex.ru
} 
expansion of opportunities of the coastal territory and sea in the recreational purposes is required for performance of this task [1-5].

Sea tourism and yachting actively develop in Russia in recent years. Experiment of functioning of the international sea resorts is shown by importance of yachting as one of the important directions of development of modern tourism. Yachting and the coastal marine transport are active elements of system of the organization of full tourist activity of sea resorts.

Experts estimate possibilities of the Black Sea coast of the Russian Federation for development of yachting as very considerable. On the Black Sea coast owing to the developed character of his urbanization, it is expedient to develop area of intensive yachting on all coast. Creation of modern objects of yachting: yacht harbors, aqua parks, touristic complexes is one of the important directions of development of tourism on the Russian Black seacoast. These objects will increase quality of rest, developing tourist activity they create area of intensive yachting as an element of sea tourism, create new jobs. The scheme of tasks of the program of development of yachting in the region is provided in fig. 1 [6-7].

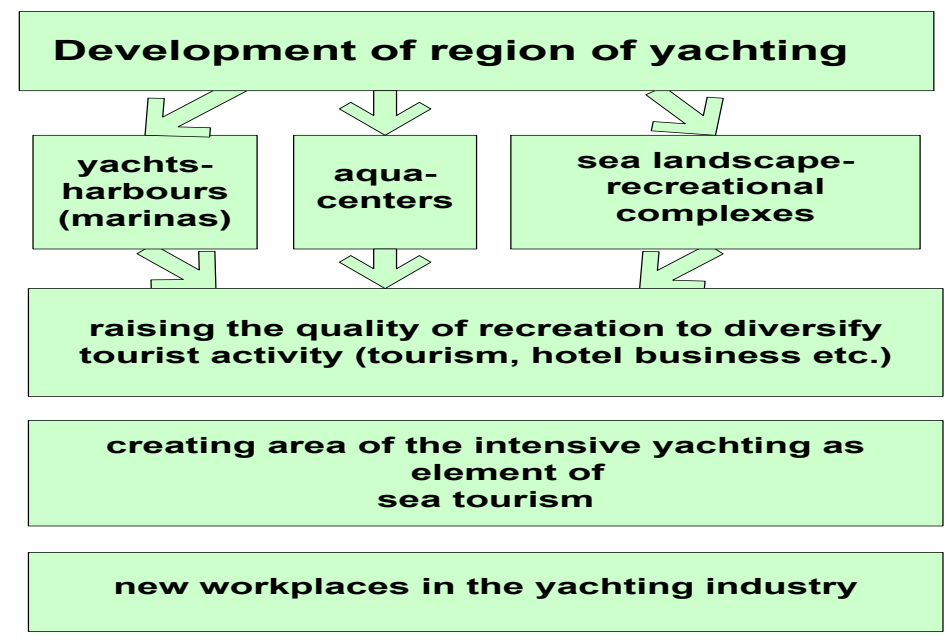

Fig. 1. The scheme of tasks of the Federal program "Development of the yachting"

Federal Program of reconstruction and creation of coastal infrastructure for restoration and development of passenger coastal lines include construction 10 yacht harbors, restoration and construction of more than 30 ports only on the Caucasian Black Sea coast of Russia [7-9].

The program purpose is restoring of the movement of coastal transport along the coast of region and creating of infrastructure for the sea transport along the coast of the Black Sea.

Passenger commodity turnover of local coastal lines made from 5 to 80 thousand passengers a year for certain moorings at the end of the 20th century.

Perspective development of the coastal transport and of yachting in the region have considerable potential and are connected, first of all, with development of tourism in on the Black Sea coast of Russia. Besides, development of this segment of tourism takes active measures for restoration of popularity of sea walks among tourists. The directions of this segment of regional development will depend on existence of the coastal marine transport and existence of service infrastructure for yachting.

The forecast of a passenger turnover on local lines at optimistical option of implementation of the program of development of yachting and coastal transport by 2020 can increase by $300 \%$ and reach 720 thousand passengers on year. 
The organization and work of marine coastal transport and infrastructure of yachting along the Black Sea coast of Russia have to consist in the organization of work of this transport (the small ships, yachts, boats, etc.), construction and the subsequent use of commercial objects of yachting and port piers. These objects have to be located along the coast and be used for service of passengers.

The program of formation of infrastructure of sea tourism and coastal transport on the coast can be considered for the solution of main goals of development of the region of intensive yachting. Construction new and reconstruction of the existing objects on the coast (yacht-harbor, marines, port-shelters, mooring complexes, etc.) is necessary for full functioning and creation of such optimum infrastructure of sea tourism and transport on the coast [6-9].

\section{Existing programs of the yachting and sea coastal transport development at the Caucasian Black Sea coastal region of Russia}

Russia has a territory of the Caucasian Black Sea coast. She settles down from the Kerch Strait to border with Abkhazia. The Black Sea coast is strategically important element of the transport system, which connects Russia and Northern Europe to the countries of the Mediterranean Sea (Fig. 2).

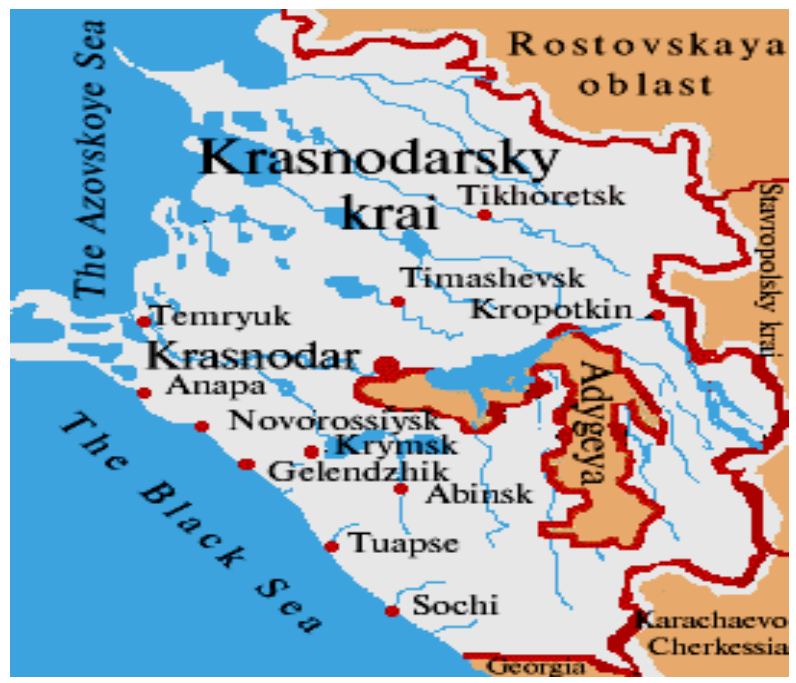

Fig. 2. Caucasian Black sea coast of Russia

Black Sea coast is the only Russian region for year-round functioning objects of tourism and recreation. Here there are cities, which name the Russian Caucasian sea resorts - Anapa, Gelendjik and Sochi. Seaports Novorossiysk and Tuapse are the main sea gate of the South of Russia. They also have the coastal territories with significant touristic potential. Modern experience of functioning of the international sea resorts evidently shows necessity of the yachting for development of regional tourism.

The Caucasian Black Sea coast of Russia has very few closed bays and natural harbors, which are suitable for placement of marines.

Existing the trading port and sports yacht-harbors in Sochi (Fig. 3) is used for the longterm parking of yachts and not satisfy even a minimal requirement of city and region for yachting development. 


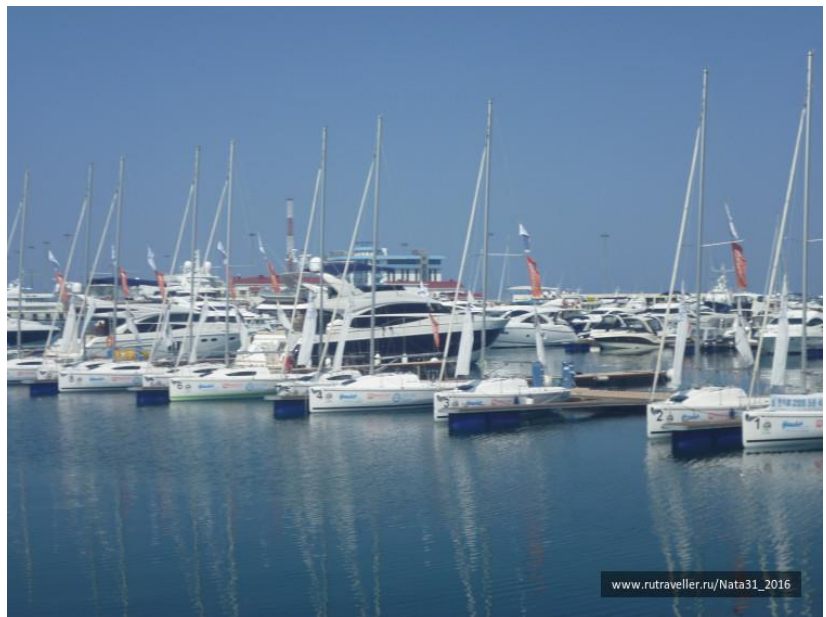

Fig. 3. The Sochi trading and yacht port

Sports yacht-harbor in a mouth of river Bzugu have protective constructions in the common extent more than 250 meters and are cannot provide parking even 10 big yachts (Fig. 4). The complete description of possible types of objects of yachting, versions of engineering decisions for their construction is shown in [6-9].

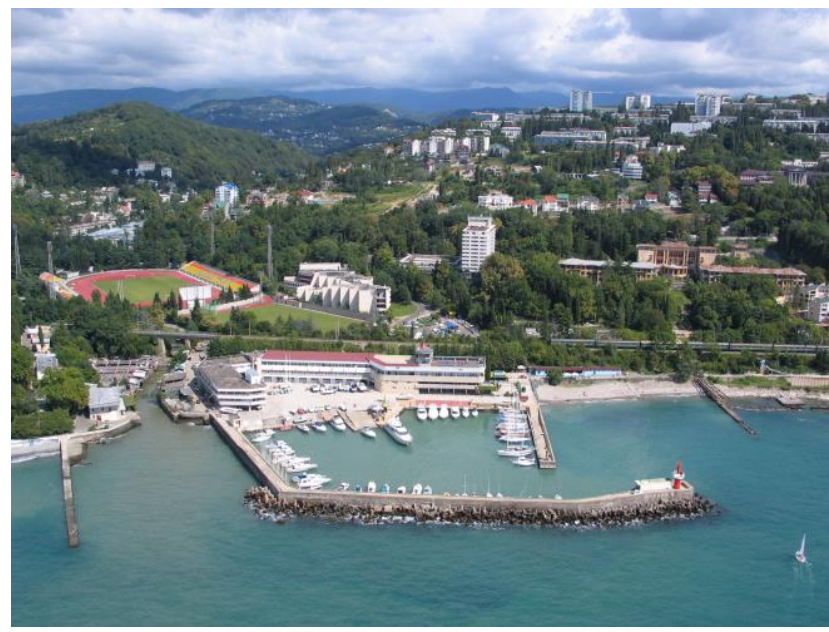

Fig. 4. Sochi sports yacht-harbor

It is expedient to develop intensive yachting in various options on the Black Sea coast of Russia that stretches on $300 \mathrm{~km}$ from Anapa to Sochi inclusive. Possible engineering solutions of objects of yachting are yacht harbors or pier for yachts, the centers of water, the sea entertaining landscape complexes. They will increase quality of rest and will expand tourist activity in the region (tourism, hotel business, etc.) [5-8].

It is planned more than 20 big yacht harbors or piers for yachts, aqua-centers with earth entertainment complexes along all coastal zone of the Russian Black Sea coast are according to the regional program of design, construction and development of yachting. The estimated scheme of an arrangement of design of yacht-harbors, piers for yachts and aquacenters is given in fig. 5 [6-9]. 


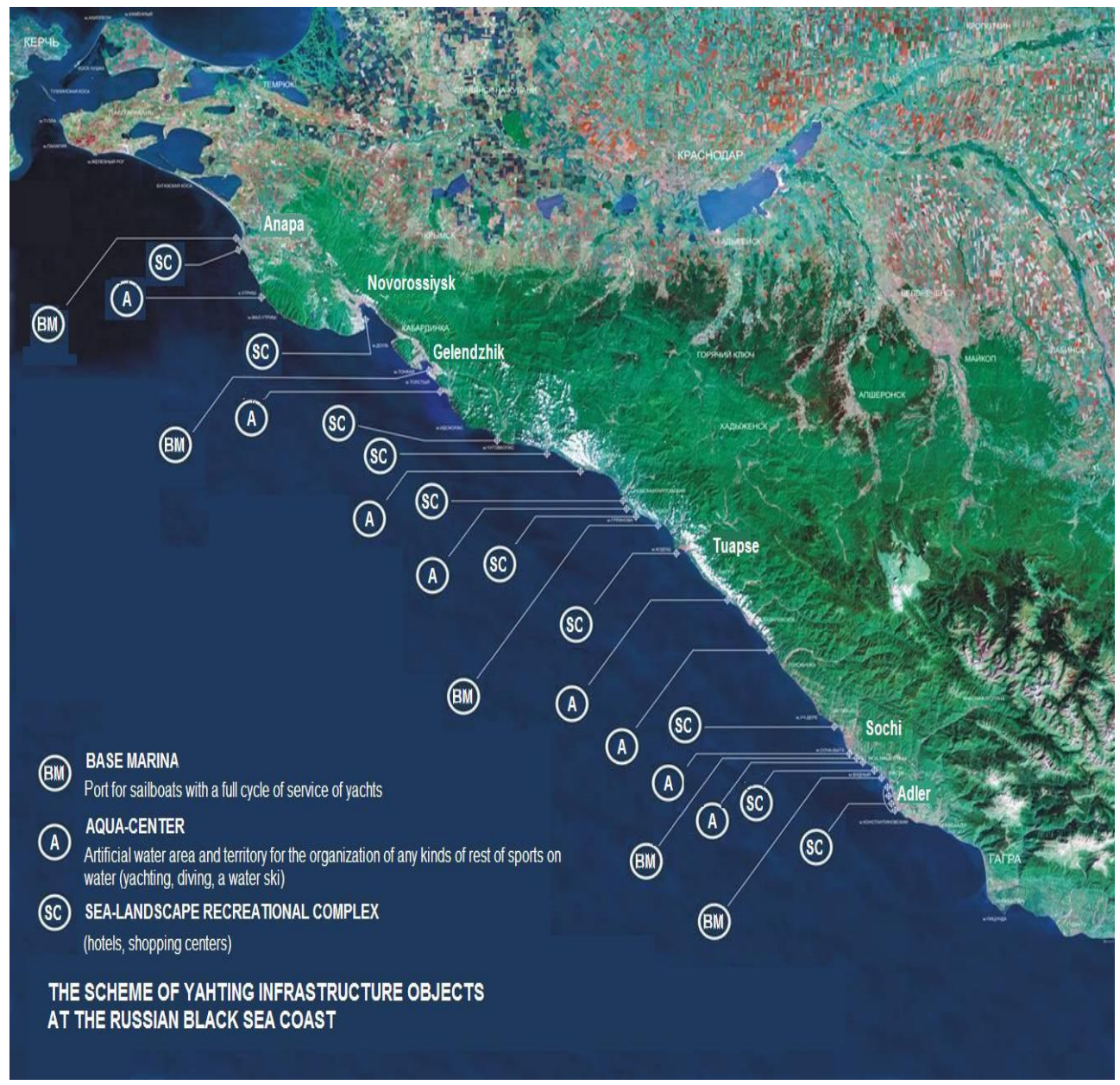

Fig. 5. The circuit of a disposition of yachts-harbours (marinas) at the Russian Black Sea coast

The scheme defines dislocation of the basic marines providing full range of services to yachtsmen, and other contingent of vacationers. Schema provides the safe parking of swimming means under any weather conditions and the high level of technical service.

Besides, construction of additional ports shelters, road moorings, water parks and reconstruction of the existing ports is expedient for improvement of service conditions of the yachting.

\section{Main versions of constructive decisions for yachting objects}

Today use of the yacht harbor as places for the parking of yachts and placement of yacht service is only a part of functions of multilateral operation of an object under the general name "Marine". Appointment of the marine has changed in comparison with initial appointment - to provide services to yachtsmen and ship-owners. Purpose of the yacht harbor is much broader now. Yacht harbors become the place of a coastal zone, which contributes to the development of all elements of infrastructure of a coastal zone [6-7, 10-11].

The choice of constructive decisions and the location of yacht harbors and functional purposes of separate elements at their construction for the Caucasian Black Sea coast of Russia are defined by many conditions:

a) the marine has to provide convenient and safe operation and the parking of boats and yachts under any weather conditions; 
b) the territory of a marine has to provide placement of a complex of buildings which correspond to purpose of a marine in a range of the provided services;

c) construction of marines has to be made with minimum possible withdrawal of the city earth in the most expensive coastal zone;

d) construction of marines has to minimize losses of the beach. Territories of many coastal cities have deficiency of beach territories already today.

The practical lack on the Black Sea coast of Russia of natural bays, suitable for marines, allows carrying out construction and functions of yacht-ports of open type. The territory of the marine has to contain all elements providing safety and service of yachting. Practice shows that open ports in the form of the uniform harbor open with two or three parties, don't provide the safe parking of yachts. The scheme of yacht-harbor at which the operational water area is divided by piers into several harbors (the ladle scheme) is preferable [6$11]$.

The construction "Cascade". The cascade constructive scheme is often used and has well proved in the international practice. The cascade scheme of port in coastal zone is more economical and simple in construction (small depths of construction, a possibility of the beginning of working of port during construction), but leads to considerable losses of a beach strip. It is possible to prevent or reduce losses of beaches if to build the yacht-harbor as the island or to unite cascade schemes. Such schemes allow not only to reduce to a minimum of loss of the beach as a touristic element, but also to organize the construction of a multipurpose coastal complex for different tourist functions [6-11].

The cascade scheme of marines allows construction in turns with considerable time intervals. It is economically expedient and allows up-dating projects at change of initial requirements.

Construction of water parks and ports-shelters besides basic marines is necessary for formation of the region of intensive yachting and the maximum involvement of the coast in development of tourism.

The water park represents a complex of the yacht-harbor and the water territory adjoining him. The water park provides a full range of services to the contingent of tourists, including a technical service, service for passive and for active recreation on water (rent of the equipment and training for various water sports: yachting, diving, rowing, water ski, hydro cycles and also sea sights, excursions etc.).

The water park can represent specialized water areas with the construction protecting them from the high sea "an artificial reef".

Water parks can incorporate aquariums and aqua parks; sea museums of navigation, sea flora and fauna, etc.

Ports-shelters of the yacht represent the protected water areas of the small size. They are intended for safe docking of yachts in case of adverse conditions of navigation with provision of the minimum volume of services. Shelters of yachts can be integrated with water parks in one complex which integrates their functions..

Multipurpose artificial islands. The urbanization and development of coastal tourist territories of the Black Sea coast of Russia have led to the fact that in these territories it is already impossible to place sailing objects without emergence of the interdepartmental conflict. Often it is impossible also for other reasons - undesirability of withdrawal of valuable beach territories, probability of negative ecological consequences, etc. Structures of yachtharbors in such territories and the functioning tourist beach complexes, as a rule, have no opportunity to offer service of yachting and diving, or to have problems with providing such services. Therefore, a design of multi-purpose entertainment complexes of island type on an artificial basis is more expedient.

Water parks. Engineering solutions of this look allow receiving considerable additional artificial territories and the protected water area for the year-round mooring of yachts. At 
the same time also the territory of beaches in comparison with the existing beaches increases. The received artificial territory allows placing hotel and various recreation areas, sports and exhibition complexes. As a result the multipurpose tourist complex can be created on the coast [6-11].

Construction of 6 yacht objects is planned along the coast of Greater Sochi according to the scheme of yachting (Fig. 5). They have to provide the parking and service of yachts and various tourist activities (hotel business, rest, spa, etc.). Model schemes of some designed yacht-harbors within Sochi region are submitted in Fig. 6-8.

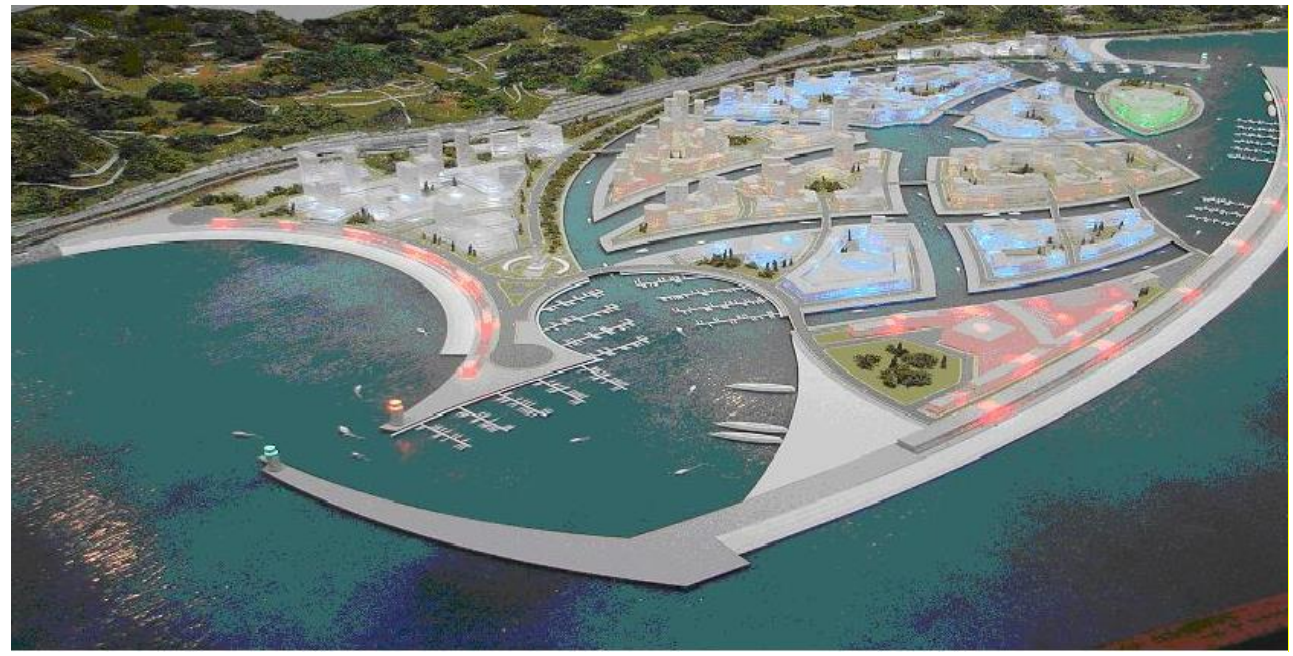

Fig. 6. Marina "New coast" (project). The area of artificial territory - 72 ha. Capacity of the marina (quantity of lay places): yachts, including length up to $100 \mathrm{~m}-1500$. Average/the-maximal depths of building of hydraulic engineering constructions $-12 / 25 \mathrm{~m}$.

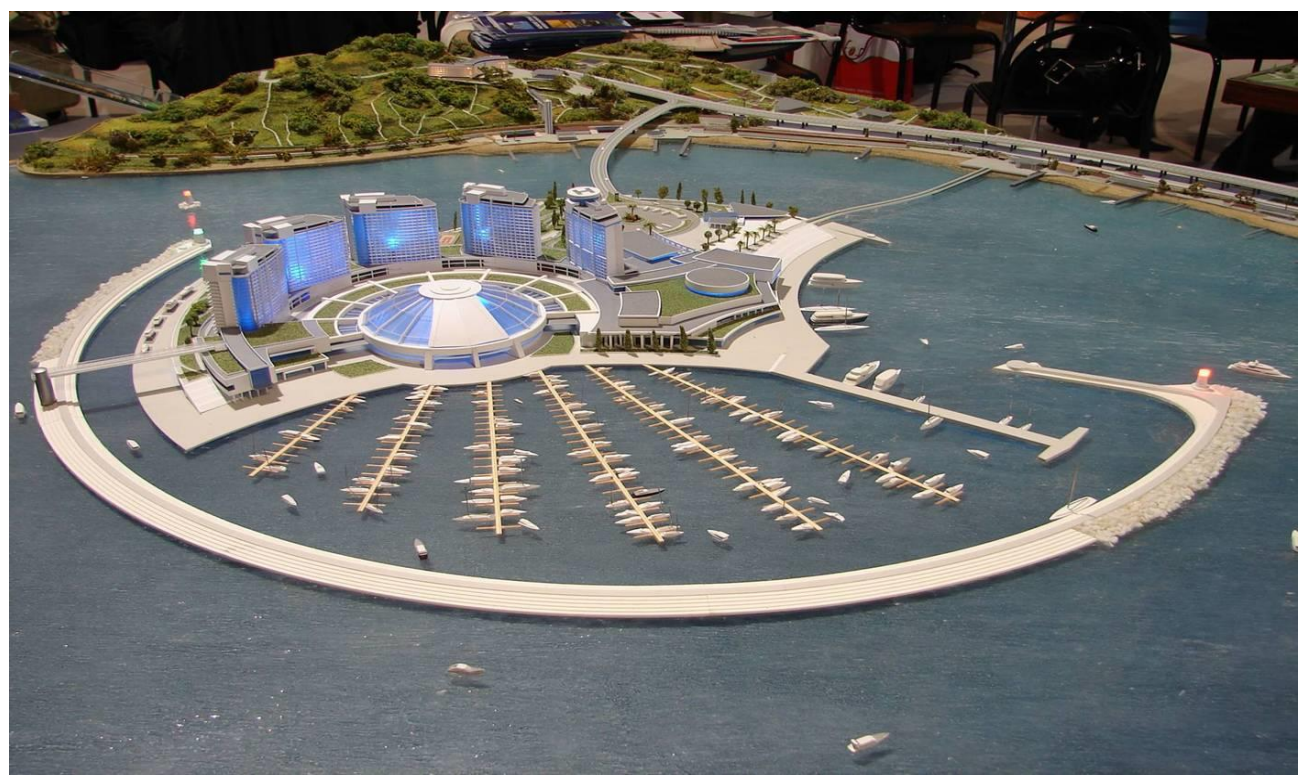

Fig. 7. Marina "Homar" (bay "Khostinskaya") (project). The area - 23 ha. The maximal depth of construction $-12 \mathrm{~m}$. The beginning of construction - the end of 2008. Duration of the island construction -2 years. Capacity of the marina -600 yachts. 


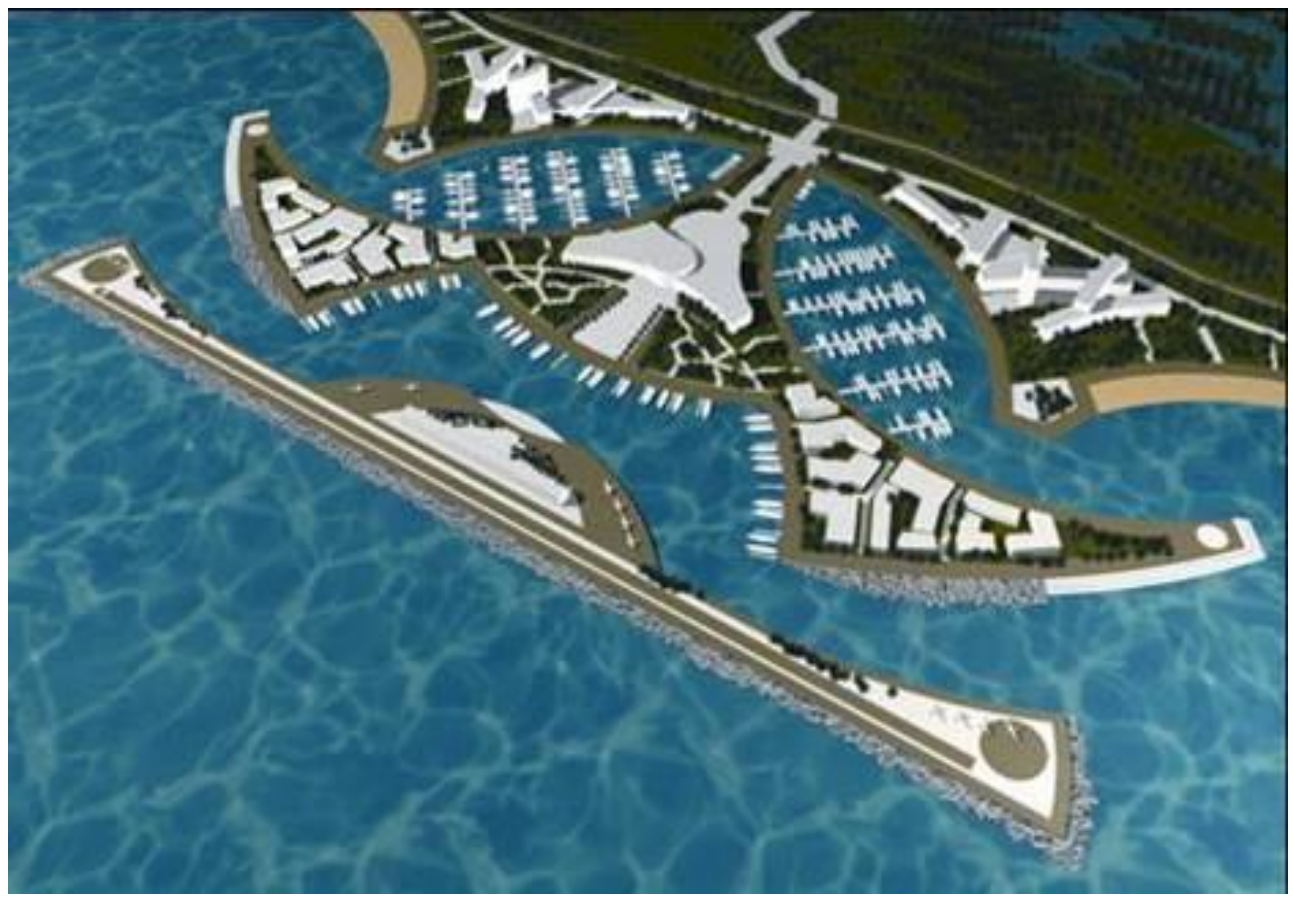

Fig. 9. Marina-village ("Dagomar") on 800 yachts (project). A southern coast of cape Uch-Dere in settlement Dagomys (Sochi region)

These yacht-harbors represent construction, considerable on amount of works. This construction will be carried out on the seacoast and on artificial islands of different constructive type. Islands will be located at considerable distance from the coast and will be connected with him piers or bridges [6-11].

\section{Assessment of the main results of implementation of the pro- gram and existing problems of the yachting development and coastal sea transport at the Caucasian Black sea coast of Rus- sia}

Problems can appear at development of yachting on the Russian Caucasian Black sea coast. These problems can create additional difficulties for development of yachting and coastal transport.

1. Engineering-environmental problem. Considerable influence on the water environment during construction, operation and service of yachting in a coastal zone depends on features of estimated field of construction, such as type of land deposits, degree and features of additional pollution, existence of beaches near yacht-harbor, the power of a coastal flow of deposits, the nature of an erosion of the coast, existence of other external sources of pollution of sea water, etc.

It is also necessary to consider a yacht-harbor configuration, sizes of the yacht-harbor, extent of interruption of the flow of deposits, technologies of refusal in the earth during construction, the schedule of work, the estimated equipment for operation and service of yachting, other recreational activity at assessment of influences on the water environment from yachting. 
2. Problems of legal character. Questions of the organization of yachting in the law "About Borders of the Russian Federation" differ from the international sea law concerning yachting (navigation in the Russian territorial waters, requirements in port, sanitary and epidemiological control, border control, passport and customs control, etc.). The situation existing now in the legislation of Russia doesn't contribute to the development of yachting in the region.

3. Problems of the organizational character are connected with backwardness of service infrastructure of yachting. These are problems of updating of reserves of fuel, food, water, a problem in rendering the technical and operational assistance, a problem of the organization of reception of tourists, customs questions, problems of planning of the yacht movement, the organization of their safety outside yacht harbors, etc.

Construction of yacht harbors, their subsequent service can lead to growth of negative impact on the water environment. Therefore obligatory assessment of influence of such objects on the environment for the purpose of determination of ecological admissibility of such objects according to the legislation of the Russian Federation is necessary.

The solution of the following problems is necessary for achievement of this purpose:

- to define types and degree of danger of all possible impacts on the environment at construction and further service of yacht harbors;

- to estimate ecological, economic and social consequences of these influences;

- to minimize influence and their possible dangers as a result of such activity;

- to accept ecological administrative decisions concerning the planned activity.

Construction of these objects will cause the following influences on the environment [12-13]):

- deformation of a seabed;

- reduction of impact of light on sea water, reduction of transparency of water at realization of works on deepening of a seabed and at hydrotechnical construction of yacht harbors;

- change of structure and structure of granulometric characteristics of the territory of works (an underwater sea slope, territories adjoining to the coast);

- increase in noise level owing to construction works, at service of yachts and other vessels, works on deepening of a bottom, works on a stroitelsv of piers, etc.;

- pollution of the water environment owing to possible dumping of mineral oil from vessels and various equipment at stages of construction and the subsequent service of the yacht harbor;

- unauthorized dumps and dumping of technical and household waste from vessels and infrastructure facilities of yachting;

- leakages of pollution from the coast when carrying out construction works in the adjacent territory;

- pollution by substances of land streams when working on deepening of a bottom of the yacht harbor;

- the dynamic loading arising at construction works, etc.

At an operation phase projected yachts-harbours essentially also will influence and a picture of circulation of currents in a coastal zone. Especially it may be shown in deterioration of water exchange with the sea semi-closed water areas formed by constructions of yacht-harbor. Frequently speaking on behalf of coast aside starve, hydraulic engineering constructions of yacht-harbor change structure of current within the limits of water area protected by them and cause development of own local circulation which prominent feature are vorticose movement of water and occurrence of stagnant zones in rear of constructions.

In addition, construction of yachts-harbors will disturb a natural mode of movement of deposits. Hydraulic engineering constructions will cause changes in a configuration of a coastal line and in full or in part block the longshore stream of deposits. 
Thus, construction of these objects inevitably will result in change of currents, to interruption of a stream of the inert material and at a service phase will cause stagnation of water in the water territory formed by hydraulic engineering constructions of yacht-harbor.

Influence on the water environment during construction and marinas service depends:

- - from hydro and meteorological characteristics of area of construction,

- - from a degree and the characteristic of pollution of land and inert material,

- - from presence of beaches, capacity of longshore flow of deposits,

- from character of erosion of a coast,

- from background pollutions,

- from a sources of pollutions of sea water,

- from a scheduled arrangement of marina,

- from configurations of hydrotechnical objects and their designs,

- - from works on a deepening of a sea bottom (alignment of a sea bottom under constructions, maintenance of navigable depths, replacement of a ground),

- - from technologies and volume of a withdrawals of the earth during construction, terms of works,

- - from the plan of manufacture of works,

- - from used types of engineering solutions, $\square$

- - from prospective equipment of marina for yachting maintenance and other recreational activity,

- - from a scheduled arrangement of marinas,

- - from configurations of hydraulic engineering constructions and their designs, and etc. sis.

The large number of the influencing factors demands their generalization and the analy-

It is necessary to predict these influences, to estimate the damages corresponding to them and to provide minimization of the integrated damage of ecology to rational management of natural resources and preservations of the environment.

The following influencing factors can be considered main on extent of ecological impacts on the water and geological environment at construction and service of the yachtharbor:

- extent of interruption coastal stream of deposits;

- degree of isolation of internal water territories of the yacht-harbor from the water area of the sea;

- amounts of works over deepening of a seabed;

- intensity of dumping of fuels and lubricants and mineral oil;

- intensity of dumping of household and industrial wastes, pollution.

The research of these features and development of the corresponding methods will allow defining the integrated damage of ecology from construction and service of the yacht harbor.

Assessment of the importance of influence of works on deepening of a seabed on the environment can be determined by the following key parameters:

- on extent of pollution of water resources in various time points and at the maximum distances from a pollution source to borders of zones with concentration which exceeds the set size;

- on the maximum area of contamination of the territory of a coastal zone of the sea which is reached during the period of construction works;

- on concentration of pollution outside the yacht harbor and the maximum distances of distribution of concentration of pollution during the entire period of works. 
The received assessment of features of influence on the water environment from works on deepening of a seabed can be included in the general integrated assessment of the ecological influences connected with construction of yacht harbors.

\section{Measures for prevention of inadmissible consequences for a coastal zone of the sea which can be connected with develop- ment of yachting and the coastal marine transport in the region}

Disintegration of the Soviet Union has made impossible for many territorial organizations in the sphere of the coastal protection to execute him functions of the client, the general contractor and the service organization in one person. It has resulted in instability in the solution of problems of the coastal protection and became the reason of catastrophic consequences as a result of violation of natural problems on certain sites of the coastal zone. These consequences have caused losses of valuable coastal territories and reduction of beaches; have led to additional financial and material expenses on carrying out expensive compensatory actions and beaches protection actions.

It is necessary to change philosophy of tourist development of the Black Sea Coast in modern social and economic conditions, to define new approach to development of coastal territories in a combination of science, economy, and ecology, town planning and technical solutions.

The coastal zone of the Black Sea region of Russia develops not systemically now. The chaotic urbanization of recreational zones of the coast, destruction of the existing technical coastal protective structures takes place. Deterioration in a condition of a coastal strip in general with losses of her recreational and tourist potential is observed.

Reasons of such situation [6-11]:

- there is no uniform approach to coastal protection. Different ways of coastal protection and protection of a coastal zone were applied in various territories in Soviet period;

- heritage of not thought over engineering decisions for minimization of costs of the protection of the coastal line and a railroads and highways passing near coast;

- functionally inexpedient use of valuable coastal territories for tourist and recreational tasks;

- unjustified construction in a shore and occupations of the coastal territory;

- a lack of the state budget and departmental financing for repair and reconstruction of bank protection constructions.

Reduction of length and area of beaches, erosion of territories, destruction of coast protection, not optimal and not effective technical solutions for hydrotechnical constructions and their weak influence on protection of beaches is result of this.

The main objective that the Black Sea cities of Russia have to solve can be formulated as follows: transformation of the existing coastal zone to a modern tourist and recreational megalopolis on all distance on the Black Sea coast of Russia. The purpose is providing a maximum of convenient conditions for tourists, yachting at the high level of investment attractiveness of coastal zone territories.

The following conceptual principles underlain in the new scheme of coastal actions have been defined as a result of systematization and the analysis of the available information and an existing effective approaches to protection of coastal territories, development of yachting, development of tourism and coastal rest, architectural view of coastal cities, technical and transport infrastructure, etc.:

1. Principle of statehood. A coastal zone of the Black Sea coast of Russia is most valuable seaside recreational territory, is a marine health resorts of Russia. 
2. Principle of a priority. Complexes of beaches and objects of an infrastructure of yachting should become basic elements of seaside resort economy. The sea health resorts of Russia are to use a huge recreational potential of the sea.

3. Principle of the landscape architecture. A new architectural image of sea resorts should organically integrate with historically developed image of seaside cities and settlements.

4. Principle of active coastal protection. Coastal protective structures have to neutralize actively impact of sea waves on the protected territories and yacht harbors. They also have to stabilize or improve situations with an existing beaches and the coastline..

5. Principle of a reasonable urbanization of territories. Objects of the yacht harbor have to provide to tourists the obligatory level of comfort and a range of necessary services. At the same time, they shouldn't reduce the level of tourist and recreational opportunities of the territory.

6. Principle of a universality of structures. All engineering structures should be multifunction.

7. Principle of ergonomics. It is necessary to create maximum comfortable and secure environment for the tourists. It is impossible without transport service of objects. It is necessary to bear technical zones for service near beaches.

9. Principle of aesthetic environment. The engineering structures and architectural appearance of buildings must harmonically integrate with a landscape and with existing style of objects of yachting and recreation.

10. Principle of compensation of territories. It is impossible to allow reduction of the area of the most popular and, respectively, the most visited beaches. Change of their functionality is possible only along their water border, for example, promotion of new objects (marina, yacht-harbor) in the sea.

11. Principle of ecology. Coastal structures, including yachting objects, have to improve an ecological situation of the coastal region and adjacent territories.

\section{Conclusion}

It is possible to note, the development of models of an estimation of influences and techniques of definition of integrated parameters of ecological damage is necessary for an estimation and reduction of influences on an environment and maintenance of steady development of chosen sites of the Russian Black Sea coast for creation of yacht-harbors (marinas).

The following results can be achieved at the embodiment of conceptual offers of yachting development on the Black Sea coast of Russia [6-11, 14-15]:

\section{TOWN-PLANNING}

- qualitative meliorating of functional usage of an inshore recreational zone of Russia Black Sea Coast;

- warning of unsystematic urbanizing of coast zone;

- change of architectural appearance of the entertaining and urbanized complexes in a coastal zone, use of essentially new architectural elements;

- creation of the district of the intensive yachting as element of the marine tourism.

\section{ECONOMIC}

- engaging of the off-budget investments;

- increase of substantial cost of the land lots of a coastal zone and of near coast territories;

- magnification of a commercial effectiveness of service on an objects of coastal zone;

- development of new industries and service in the region; increase in capacity of hotels and other vacation spots of tourists at the coast

\section{SOCIAL}


- creation of new jobs in various spheres of regional economy;

- construction, service, public catering, etc.;

- development of peripheral areas of the region;

- valuable use of various recreational resources of the coast.

\section{ECOLOGICAL}

- improvement of an ecological situation in the coastal territory and near a coastal zone;

- positive influence on dynamics of preservation of natural resources of the coast and development of a biocenosis.

The proposed solutions, including offers on development of a coastal zone, development of yachting and the coastal marine transport, will allow creating a modern recreational, tourist and resort environment on the Black Sea coast of Russia. This complex environment will be able to provide the organization of good comfortable and convenient rest on the Black sea coast of Russia. She will contribute to the further complex development of this coastal region.

The prospects of creation of group of yacht harbors and piers on the Black Sea coast of Russia (more than 30) are the necessary need for a solution of the problem of further development of the region.

It is defined also by requirement of introduction of the program of development of the tourist industry in the territory of Krasnodar Region.

Introduction of the program of development of yachting infrastructure and the coastal marine transport has to be connected with the program of the integrated management of a coastal zone (ICZM) for the Black Sea coast regions of Russia and correspond to her basic principles [14-15].

Only the integrated and universal system approach to introduction of the program development of the yachting in the region will contribute to the system development of the Caucasian Black Sea coast of Russia as the sea recreational region with the wide list of the provided tourist and recreational services.

\section{References}

1. Nauchnyy otchet "14-ya Podprogramma Federal'noy tselevoy programmy razvitiya goroda-kurorta Sochi na period do 2020 goda". Nauchno-tekhnicheskiy tsentr "Spark", Sochi, (1996)

2. N. A. Grishin, E. V. Serebrjakov, L. K. Zvukov Problemy ustoychivogo razvitiya regionov s rekreatsionnoy spetsializatsiey Izdanie Sochinskogo nauchnogo tsentra Rossiyskoy Akademii nauk, Sochi, 21-24 (2000)

3. N. A. Grishin Infrastruktura yakhtinga kak odin iz faktorov ustoychivogo funktsionirovaniya rekreatsionnoy sistemy Bol'shogo Sochi. ). Sb. trudov nauchnoy konferentsii "Problemy ustoychivogo razvitiya regionov s rekreatsionnoy spetsializatsiey". Sochi, iyul' 2001, Izdanie Sochinskogo nauchnogo tsentra Rossiyskoy Akademii nauk, 2001, S. 255-268 (2001)

4. N. A. Grishin Problemy ustoychivogo razvitiya regionov s rekreatsionnoy spetsializatsiey Izdanie Sochinskogo nauchnogo tsentra Rossiyskoy Akademii nauk, 44-50 (2002)

5. Y. I. Dreizis, K. N. Makarov Proc of the Sixth Int. Conf. On Coastal \& Port Engineering in Developing Countries. Colombo. Sri Lanka. no. 186. 17 p. (2003)

6. Yu. Dreyzis, E. Bondareva, I. Proc. of MED \& Black Sea ICM 08 International Conference, Turkey, 14-19.10.2008 (2008) 
7. Yu. Dreyzis, E. Bondareva, N. Grishin, I. Proceedings of the 7 International Conference «COPEDEC VII», (2008)

8. Yu. I. Dreyzis, E. V. Bondareva, I. G. Kantarzhi Nauka Kubani, Krasnodar, izd-vo "Obrazovanie-Yug", 2008, t. 3, s. 53-64 (2008)

9. Yu. I. Dreyzis, E. V. Bondareva, I. G. Kantarzhi, L. V. Prokhoda-Shumsky Trudy IX Mezhdunarodnoy nauchno-prakticheskoy konferentsii Problemy, innovatsionnye podkhody i perspektivy razvitiya turizma. Sochi, SGU (2009)

10. URL: http://www.blackseanews.net/read/9741 (2011)

11. URL: http://yachtsworld.ru/article.php?view=128454 (2012)

12. I. Kantardgi, Yu. Dreyzis, L. Prokhoda-Shumskikh Proc. of MED \& Black Sea ICM 08 International Conference / Workshop. Akyaka, Turkey, 14-19.10.2008, 12 p. (2008)

13. Yu. I. Dreyzis, I. G. Kantarzhi, V. V Vaytman, L. V. Prokhoda-Shumsky, E. V. Bondareva, V. S. Shevtsov Nauchnyy otchet po grantu RFFI No. 08-05-99025, VNIITS, Moskva, No. 0120903926, 256 s. (2010)

14. Yu .I. Dreyzis, Global Journal of Human-Social Science: B. Geography, GeoSciences, Environmental Science \& Disaster Management, USA, 16, Issue 5, 37-56 (2017)

15. Yu .I. Dreyzis, I. G. Kantardgi A Review of ICZM Along The Russian Black Sea Coast. Proc of MEDCOAST 2017, Malta, 2017, Vol. 1, pp. 13-25 